\title{
RARE EARTH ELEMENTS IN PROTEROZOIC METABASALTS AND ASSOCIATED VOLCANOGENIC SULPHIDE ORE FROM HAVERI, SOUTHWESTERN FINLAND
}

\author{
Y. KÄHKÖNEN, K. MÄKELÄ and R. J. ROSENBERG
}

\begin{abstract}
KÄHKÖNEN, Y., MÄKELÄ, K. and ROSENBERG, R. J. 1981: Rare earth elements in Proterozoic metabasalts and associated sulphide ore from Haveri, southwestern Finland. Bull. Geol. Soc. Finland $53-1,11-16$.

REE data on two tholeiitic metabasalts and a metalava breccia from the Haveri formation display a coherent distribution pattern from La 28 to Lu 7 times that of chondrite. Such contents and LREE enrichment have been observed in some tholeiitic basalts from marginal basins, Archean greenstone belts, and calc-alkaline basalts from island arcs. REE distribution in a submassive sulphide ore overlying metalava breccia is from La 6 to $\mathrm{Lu} 2$ times that of chondrite. A positive $\mathrm{Eu}$ anomaly is recorded in both the epidotized metalava breccia and the genetically related sulphide ore. It is suggested that $\mathrm{Eu}$ could be used as a pathfinder in the exploration of volcanic exhalative ore deposits.
\end{abstract}

Y. Kähkönen, Department of Geology, University of Helsinki, P.O. Box 115, SF-00171 Helsinki 17, Finland.

K. Mäkelä, Outokumpu Oy, P.O. Box 27, SF-02201, Espoo 20, Finland. R. J. Rosenberg, Reactor Laboratory, Technical Research Centre of Finland, SF-02150 Espoo 15, Finland.

\section{Introduction}

The purpose of this study is to give fresh information on the contents and distribution of rare earth elements (REE) in Finnish metabasalts and associated volcanogenic sulphide ores, to compare these rocks with basalts from various environments and ages, and to discuss the behaviour of REE in volcanogenic ore-forming processes.

One of the authors (KM) supervised exploration drilling for Outokumpu Oy in the environment of the exhausted Haveri mine in 1977. The four samples studied are from these drill holes.

\section{General geology}

The Haveri mine is located at Viljakkala, roughly $35 \mathrm{~km} \mathrm{NW}$ of Tampere. The drill holes mentioned above are $0.3-1.0 \mathrm{~km}$ south of the mine. The pyrrhotite-dominated goldcopper ore deposits in and around the mine are closely associated with tholeiitic metabasalts, metalava breccias and related rocks; the whole sequence is known as the Haveri formation (Mäkelä 1980). The ore-forming metals originate from metalava breccias through leaching by hydrothermal fluids (heated sea-water), and the sulphur originates from contemporaneous sea-water. The mas- 
sive sulphides (mainly pyrrhotite with some chalcopyrite and minor pyrite) deposited under hydrothermal (volcanic exhalative) conditions. The sulphides commonly display banded structures indicating deposition on the sea-floor. The conditions during the main ore-forming stage have been estimated at: temperature $250^{\circ} \mathrm{C}, \mathrm{pH} 5$, oxygen fugacity $10^{-40}$ atm., and minimum pressure 40 bar (Mäkelä op. cit.).

The geology, geochemistry and origin of the metabasaltic rocks and associated ore deposits from Haveri have been described and thoroughly discussed by Stigzelius (1944) and Mäkelä (1980). It was suggested that the original geotectonic setting of the Haveri formation was an initial-stage Svecofennidic island-arc. The massive sulphide deposits within it were correlated with those of the Cyprus type. The regional metamorphic conditions in the Haveri district were estimated at c. $550{ }^{\circ} \mathrm{C}$ temperature and $2.5 \mathrm{kbar}$ pressure (Mäkelä 1980).

\section{Description of samples}

The samples studied are typical of the $\mathrm{Ha}$ veri formation. The following is a brief description of each of them.

Sample 1 is a dark green metabasalt that, except for some green/grey-mottled breccialike features, is fairly homogenous by structure. Microscopic examination shows that the rock is composed of dark green hornblende and plagioclase $\left(\mathrm{An}_{40}\right)$ with quartz, opaques, biotite and sphene as main accessory minerals. The grain size varies from 0.05 to $0.1 \mathrm{~mm}$, and the texture is granoblastic.

Sample 2 is a dark green, massive intersection of a metabasalt or, partly at least, of a feeder dyke. The rock is composed of pale green amphibole often with crystal accumulations pseudomorphic after pyroxene (c. 30 vol- $\%$ of rock), and of plagioclase $\left(\mathrm{An}_{30}\right)$. Bio- tite and sooty, pigmenting opaques are associated with the amphibole. The size of the pyroxene pseudomorphs is $1 \mathrm{~mm}$, and the grain size of the plagioclase $0.05 \mathrm{~mm}$.

Sample 3 is a dark green/white-mottled metalava breccia originating from brokenpillow breccia structures. The constituent minerals are bluish green hornblende, epidote, quartz and sphene. No plagioclase is present. The accessory minerals include opaque and carbonate. The grain size averages $0.1 \mathrm{~mm}$, and the texture is granoblastic.

Sample 4 is a "massive sulphide» intersection, stratigraphically overlying and genetically related to the metalava breccia. The sample contains c. 40 vol- $\%$ pyrrhotite and some chalcopyrite, occurring as the matrix in a dark green metalava breccia. The rock is composed of bluish green hornblende, epidote, quartz and opaques. The opaque minerals include pyrrhatite and some chalcopyrite with accessory magnetite, pyrite and cobaltite. The grain size varies from $0.05 \mathrm{~mm}$ to $0.1 \mathrm{~mm}$, and the texture is granoblastic.

\section{Results}

Table 1 gives the chemical compositions, and Fig. 1 the chondrite-normalized REE distribution patterns of the four samples analyzed. The analytical methods are those referred to in Table 1 . The following features are observed in the REE distribution patterns.

All the samples are enriched in light REE (LREE) in comparison with heavy REE (HREE), and their normalized distribution patterns resemble each other (except for $\mathrm{Eu}$ ).

Samples 3 and 4 display clear positive $\mathrm{Eu}$ anomalies. The positive $\mathrm{Eu}$ anomalies displayed by samples 1 and 2 are weak and, considering the trends from $\mathrm{La}$ to $\mathrm{Lu}$, insignificant.

The REE contents in sample 4 are c. 5 times lower than those in the other samples ana- 
Table 1. Chemical analyses of the Haveri formation rock samples $1-4$ discussed in the text.

\begin{tabular}{|c|c|c|c|c|}
\hline & 1 & 2 & 3 & 4 \\
\hline $\mathrm{SiO}_{2}$ & 48.82 & 49.39 & 47.70 & 37.70 \\
\hline $\mathrm{TiO}_{2}$ & 1.91 & 1.77 & 1.68 & 0.46 \\
\hline $\mathrm{Al}_{2} \mathrm{O}_{3}$ & 13.55 & 12.45 & 9.98 & 5.04 \\
\hline $\mathrm{FeO}^{*}$ & 15.15 & 15.49 & 21.96 & 13.63 \\
\hline $\mathrm{MnO}$ & 0.29 & 0.19 & 0.26 & 0.04 \\
\hline $\mathrm{MgO}$ & 4.51 & 4.49 & 3.27 & 2.75 \\
\hline $\mathrm{CaO}$ & 10.33 & 11.47 & 11.20 & 7.10 \\
\hline $\mathrm{Na}_{2} \mathrm{O}$ & 2.16 & 3.13 & 0.83 & 0.39 \\
\hline $\mathrm{K}_{2} \mathrm{O}$ & 0.83 & 0.59 & 0.89 & 0.26 \\
\hline $\mathrm{P}_{2} \mathrm{O}_{5}$ & 0.39 & 0.44 & 0.46 & 0.09 \\
\hline $\mathrm{FeS}$ & 0.96 & 1.37 & 2.14 & 35.10 \\
\hline Total & 98.90 & 100.78 & 100.37 & 102.56 \\
\hline Co & 25 & 23 & 65 & 690 \\
\hline $\mathrm{Ni}$ & 26 & 42 & 27 & 99 \\
\hline $\mathrm{Cu}$ & 183 & 401 & 684 & 2310 \\
\hline $\mathrm{Zn}$ & 30 & 20 & 30 & 30 \\
\hline $\mathrm{Pb}$ & 10 & 12 & 23 & 33 \\
\hline $\mathrm{Ag}$ & 2 & 2 & 2 & 3 \\
\hline $\mathrm{Au}$ & 0.2 & $<0.2$ & 0.4 & $<0.2$ \\
\hline $\mathrm{La}$ & 11 & 9.9 & 10 & 2.2 \\
\hline $\mathrm{Ce}$ & 22 & 23 & 27 & 4.5 \\
\hline $\mathrm{Nd}$ & 22 & 16 & 12 & $<3$ \\
\hline $\mathrm{Sm}$ & 4.0 & 3.0 & 3.6 & 0.91 \\
\hline $\mathrm{Eu}$ & 1.5 & 1.4 & 3.6 & 0.59 \\
\hline $\mathrm{Tb}$ & 0.78 & 0.65 & 0.78 & 0.17 \\
\hline Dy & 4.4 & 3.0 & 4.5 & 0.73 \\
\hline $\mathrm{Yb}$ & 3.0 & 2.4 & 2.8 & 0.54 \\
\hline $\mathrm{Lu}$ & 0.28 & 0.26 & 0.32 & 0.09 \\
\hline $\mathrm{La}: \mathrm{Yb}$ & 3.67 & 4.13 & 3.57 & 4.07 \\
\hline $\mathrm{Eu}: \mathrm{Eu}^{*}$ & 1.08 & 1.29 & 2.77 & 1.87 \\
\hline
\end{tabular}

1. Metalava. Diamond drill hole Hvr-5, depth $111.00-114.00 \mathrm{~m}$.

2. Metalava. D.d. hole Hvr-8, depth $174.00-182.30$ $\mathrm{m}$.

3. Metalava breccia. D.d. hole Hvr-9, depth $31.80-34.10 \mathrm{~m}$.

4. Ore. D.d. hole Hvr-9, depth $29.30-31.80 \mathrm{~m}$.

The whole rock XRF, sulphide phase AAS, and sulphur analyses are routine analyses of Outokumpu Oy, Exploration. REE analyses were made at the Reactor Laboratory, Technical Research Centre of Finland (Rosenberg and Wiik 1971, and Rosenberg 1977).

Major elements are expressed in wt-\%, minor elements in ppm. $\mathrm{FeS}=\mathrm{S}$ expressed as FeS. $\mathrm{FeO}^{*}=\left(\mathrm{Fe}_{\text {total }}-\mathrm{Fe}\right.$ Fes $) \mathrm{O}$. Eu* was obtained by interpolation between $\mathrm{Sm}$ and $\mathrm{Tb}$.

lyzed, probably owing to the dilution of metalava breccia by sulphides. However, generally speaking, its chondrite-normalized pattern (LREE enrichment) resembles those of samples $1-3$ reflecting the lodging of $\mathrm{REE}$ mainly in silicates.

\section{Comparison with various basalt types}

REE are considered as a rather immobile group of elements (e.g. Condie 1976). They have therefore been used as a means of comparing volcanic rocks from different environments and ages (e.g. Jahn et al. 1974).

A feature typical of the tholeiitic metabasalts of the Haveri formation is their consistent LREE enrichment ( $\mathrm{La}: \mathrm{Yb}=3.6-4.1$ vs. c. 1.6 in chondrites). La : Yb ratios of this magnitude are common in various basalts as will be shown in what follows.

Young basalts with tholeiitic affinities are found in oceanic and continental environments (mid-ocean ridges, deep ocean floors, marginal or back-arc basins, oceanic islands, island arcs, continental plateau basalts). Bryan et al. (1976) recognize two groups of basalts on the ocean floors. Group I, "normal» to mid-ocean ridges and ocean floors, is characterized by LREE depletion ( $\mathrm{La}: \mathrm{Yb}<$ 1.1) whereas group II is heterogeneous and commonly LREE enriched (La : Yb ratios generally $>2$ ). Note that group II basalts have been found in nearly every oceanic environment, including mid-ocean ridges. Basalts from marginal or back-arc basins are generally tholeiitic. The $\mathrm{La}: \mathrm{Yb}$ ratios of such basalts range from 0.3 to 7 , typically from 1 to 4 (see data in Hart et al. 1972; Gill 1976; Hawkesworth et al. 1977; Saunders and Tarney 1979; Saunders et al. 1979; Stern 1979; Weaver et al. 1979).

The La: $\mathrm{Yb}$ ratios in the rocks of the island-arc tholeiitic series range from 1 to 2 (Jakeš and Gill 1970). The ratio for basalts of the island-arc calc-alkaline series is typically 3.5 (Jakeš and White 1972). La: Yb ratios of this magnitude are found in calc- 


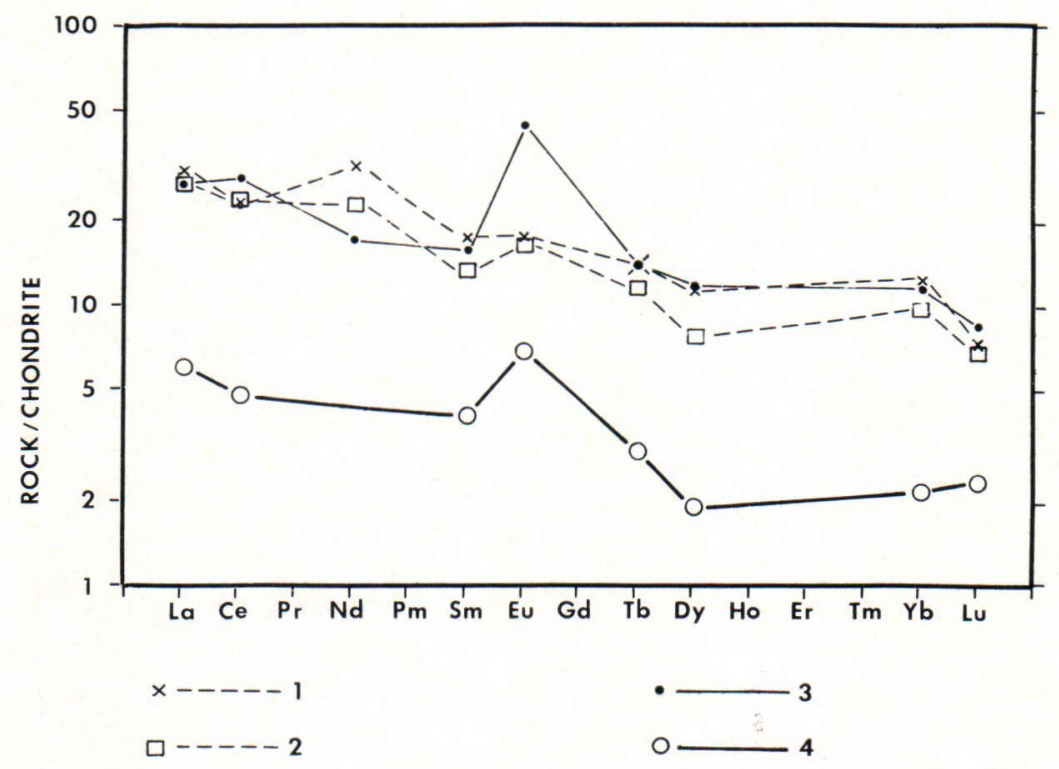

Fig. 1. Normalized REE distributions in the Haveri formation rock types (Leedey chondrite, Masuda et al. 1973; Koljonen and Rosenberg 1975). 1. and 2. metalavas, 3. metalava breccia, 4. sulphide ore.

alkaline basalts in some active parts of continental margins (Lopez-Escobar et al. 1977).

The data given by Schilling and Winchester (1969) and Herrmann (1970) indicate that the $\mathrm{La}: \mathrm{Yb}$ ratios in tholeiites from oceanic islands range from 4 to 10 , and in tholeiitic continental plateau basalts from 3 to 10 .

On the basis of averages given by Condie (1976) the La : Yb ratios of metabasalts from Archean greenstone belts range from 1.5 to 5 . The tholeiitic metabasalts from the Tipasjärvi greenstone belt display $\mathrm{La}: \mathrm{Yb}$ ratios from 3 to 5 (Blais et al. 1978, Fig. 9).

The LREE enrichment in the tholeiitic metabasalts from Haveri (La: $\mathrm{Yb} \sim 4$ ) indicates that they differ from normal (but not all) mid-ocean ridge and ocean floor basalts. For the same reason they also differ from typical basalts of the island arc tholeiitic series. On the basis of their $\mathrm{La}: \mathrm{Yb}$ ratios the Haveri metabasalts resemble some tholeiitic basalts from marginal basins and oceanic islands, some tholeiitic continental plateau basalts, calc-alkaline basalts from island arcs and some continental margins, and some Archean tholeiitic metabasalts.

\section{REE in volcanic ore-forming processes}

Conspicuous features of Fig. 1 are the positive Eu anomalies in samples 3 and 4 . Several events may give rise to positive $\mathrm{Eu}$ anomalies in rocks: (1) cumulation of plagioclase, into which $\mathrm{Eu}$ has become relatively enriched, will produce a positive Eu anomaly; (2) during the precipitation of chemical sediments Eu could preferably enter precipitating phases; (3) Eu can become relatively enriched into hydrothermal fluids; (4) $\mathrm{Eu}$ is sometimes relatively enriched during epidotization processes; (5) Eu could be enriched by metamorphic differentiation (Koljonen and Rosenberg 1974; Condie et al. 1977; Graf 1977; Hellmann et al. 1979; Kerrich and Fryer 1979). 
Samples 3 and 4 are successive samples from the same drill core; both display a positive Eu anomaly of equal magnitude. Therefore, and because similar anomalies are lacking from the metalavas, the positive $\mathrm{Eu}$ anomalies probably have a common origin.

Samples 3 and 4 are rich in epidote and therefore differ from samples 1 and 2. Hence, the origin of the positive $\mathrm{Eu}$ anomalies is attributed to the circulation of ore-forming hydrothermal fluids in the metalava breccia. These fluids are thought to have caused for the transportation of $\mathrm{Eu}$, epidotization, and the leaching and transportation of ore-forming elements (cf. Mäkelä 1980).

According to the data by Condie et al. (1977) and Hellmann et al. (1979), Eu : Eu* ratios in intensely epidotized rocks $(60-80$ vol- $\%$ epidote) are c. 1.5 . This value is lower than those for sample 4 and, especially, sample 3 (in which the quantity of epidote is c. 30 vol- $\%$ and $\mathrm{Eu}: \mathrm{Eu}^{*}$ is 2.8). This indicates that the hydrothermal fluid contributing to the epidotization and ore-forming process was relatively enriched in Eu.

\section{Conclusions}

The results of the present study indicate that in the Haveri formation the LREE contents of the tholeiitic metabasalts are 20 to 30 times and the HREE contents 6 to 12 times higher than those of chondrites. Such a LREE-enrichment pattern is found in tholeiitic basalts of various environments and ages including young marginal basins, oce-

\section{References}

Blais, S., Auvray, B., Capdevila R., Jahn, B. M., Hameurt, J. and Bertrand, J. M. (1978) The Archaean greenstone belts of Karelia (eastern Finland) and their komatiitic and tholeiitic series. Pp. 87-107 in Windley, B. F. and Naqvi, anic islands, continental plateau basalts, some Archean metabasalts, and some island-arc and active continental margin calc-alkaline basalts.

The metalava breccia produced a REE distribution pattern identical to those of metalavas except for a positive Eu anomaly. A genetically related sulphide ore sample shows a similar pattern at a lower REE concentration level, including a positive Eu anomaly.

Positive Eu anomalies have been reported by Graf (1977) from Ordovician volcanogenic massive sulfide deposits and associated rocks. Kerrich and Fryer (1979) found positive Eu anomalies in Archean auriferous carbonatechert sediments, hydrothermal quartz veins and host rocks. The results of the above and the present study suggest that a positive Eu anomaly in a volcanic rock unit implies of hydrothermal fluid circulation within the unit. Consequently, if we keep in mind the formation mechanism of volcanic exhalative ore deposits (leaching and transportation of metals by hydrothermal fluid, and subsequent deposition on the sea floor), such an anomaly might indicate the existence of a volcanic exhalative ore deposit in the environment. However, more studies on REE in volcanic rocks, related ore deposits, and minerals are required to asses the value of $\mathrm{Eu}$ as a pathfinder in the exploration of volcanogenic ore deposits.

Acknowledgements - The authors thank Outokumpu Oy for permission to use the samples and to publish the findings, and $\mathrm{Dr}$. T. Koljonen for critically reading the manuscript.

S. M. (eds.), Archaean Geochemistry. Elsevier, Amsterdam. $406 \mathrm{pp}$.

Bryan, W. B., Thompson, G., Frey, F. A. and Dickey, J. S. (1976) Inferred geologic settings and differentiation in basalts from the deep- 
sea drilling project. J. Geophys. Res., 81, 4285-4304.

Condie, K. C. (1976) Trace-element geochemistry of Archaean greenstone belts. Earth-Sci. Rev. $12,393-417$.

Condie, K. C., Viljoen, M. J. and Kable, E. J. D. (1977) Effects of alteration on element distributions in Archean tholeiites from the Barberton greenstone belt, South Africa. Contrib. Mineral. Petrol., 64, 75-89.

Gill, J. B. (1976) Composition and age of Lau Basin and Ridge volcanic rocks: Implications for evolution of an interare basin and remnant arc. Geol. Soc. Am. Bull., 87, 1384-1395.

Graf, J. G., Jr. (1977) Rare earth elements as hydrothermal tracers during the formation of massive sulfide deposits in volcanic rocks. Econ. Geol., 72, 527-548.

Hart, S. R., Glassley, W. E. and Karig, D. E. (1972) Basalts and sea floor spreading behind the Mariana island arc. Earth Planet. Sci. Lett., 15, 12-18.

Hawkwesworth, C. J., O'Nions, R. K., Pankhurst, R. J., Hamilton, P. J. and Evensen, N. M. (1977) A geochemical study of island-arc and backarc tholeiites from the Scotia Sea. Earth Planet. Sci. Lett., 36, 253-262.

Hellmann, P. L., Smith, R. E. and Henderson, P. (1979) The mobility of the rare earth elements: evidence and implications from selected terrains affected by burial metamorphism. Contrib. Mineral. Petrol., 71, 23-44.

Herrmann, A. G. (1970) Yttrium and lanthanides. 39, 57-71-E. Abundance in common igneous

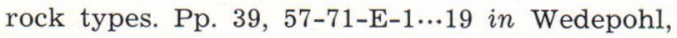
K. H. (ed.), Handbook of Geochemistry. Springer-Verlag, Heidelberg.

Jahn, B.-M., Shih, C.-Y. and Murthy, V. R. (1974) Trace element geochemistry of Archean volcanic rocks. Geochim. Cosmochim. Acta, 38, 611-627.

Jakeš, P. and Gill, J. (1970) Rare earth elements and the island arc tholeiitic series. Earth Planet. Sci. Lett., 9, 17-28.

Jakeš, P. and White, A. J. R. (1972) Major and trace element abundances in volcanic rocks of orogenic areas. Geol. Soc. Am. Bull., 83, 29-40.

Kerrich, R. and Freyer, B. J. (1979) Archaean precious-metal hydrothermal systems, Dome Mine, Abitibi greenstone belt. II. REE and oxygen isotope relations. Can. J. Earth Sci., $16,440-458$.

Koljonen, T. and Rosenberg, R. J. (1974) Rare earth elements in granitic rocks. Lithos 7, $249-261$.

- (1975) Rare earth elements in middle Precambrian volcanic rocks of Finland, with a discussion of the origin of the rocks. Bull. Geol. Soc. Finland 47, 127-138.

Lopez-Escobar, L., Frey, F. A. and Vergara, M. (1977) Andesites and high-alumina basalts from the central-south Chile High Andes: geochemical evidence bearing on their petrogenesis. Contrib. Mineral. Petrol., 63, 199-238.

Mäkelä, K. (1980) Geochemistry and origin of Haveri and Kiipu, Proterozoic strata-bound volcanogenic gold-copper and zinc mineralizations from southwestern Finland. Geol. Surv. Finland, Bull. 310. 79 pp.

Masuda, A., Nakamura, N. and Tanaka, T. (1973) Fine structures of mutually normalized rareearth patterns of chondrites. Geochim. Cosmochim. Acta, 37, 239-248.

Rosenberg, R. J. and Wiik, H. B. (1971) Instrumental activation analysis of 11 lanthanide elements in Apollo 12 lunar samples. Radiochim. Radioanal. Lett., 6, 45-55.

Rosenberg, R. J. (1977) Instrumental neutron activation analysis as a routine method for rock analysis. Technical Research Centre of Finland, Electrical and Nuclear Technology Publication 19 .

Saunders, A. D. and Tarney, J. (1979) The geochemistry of basalts from a back arc spreading centre in the East Scotia Sea. Geochim. Cosmochim. Acta 43, 555-572.

Saunders, A. D., Tarney, J., Stern C. R. and Dalziel, I. W. D. (1979) Geochemistry of Mesozoic marginal basin floor igneous rocks from southern Chile. Geol. Soc. Am. Bull., Part I, v. $90,237-258$.

Schilling, J.-G. and Winchester, J. W. (1969) Rare earth contribution to the origin of Hawaiian lavas. Contrib. Mineral. Petrol., 23, 27-37.

Stigzelius, H. (1944) Über die Erzgeologie des Viljakkala-gebietes im südwestlichen Finland. Bull. Comm. géol. Finlande, 134. 91 p.

Weaver, S. D., Saunders, A. D., Pankhurst, R. J. and Tarney, J. (1979) A geochemical study of magmatism associated with the initial stages of back-arc spreading. The Quaternary volcanics of Bransfield Strait, from South Shetland Islands. Contrib. Mineral. Petrol., 68, 151 -169 .

Manuscript received, June 4, 1980 